\title{
Det ondes familieproblem - filmskaperen Michael Haneke
}

\begin{abstract}
Sammendrag
Med den vakre og dystre Det hvite båndet fra 2009 ble den østerrikske filmskaperen Michael Haneke for alvor en internasjonal suksess. Sentralt i hans virke står tematisering av ondskapens praksis og opphav. Like viktig er hans ambisjon om en filmkunst der ondskapen ikke bare vises frem, men også hvor tilskueren utfordres til å forholde seg til sine egne etiske standarder og sin rolle som tilskuer. Haneke er en original filmskaper i sin konsekvente anstrengelse for å skape en filmestetikk som stimulerer til etisk selvrefleksjon og egenmentalisering. Og det er denne tekstens påstand at han gradvis har lyktes med dette.
\end{abstract}

Deler av artikkelen er basert på Finn Skårderuds anmeldelse av filmen Det hvite båndet (1)

\section{Finn Skårderud}

finns@online.no

Avdeling for helse- og sosialfag

Høgskolen i Lillehammer

2626 Lillehammer
I filmkretser har Michael Haneke lenge vært kjent som en regissør som fremkaller ambivalens. Jeg møtte for første gang hans filmkunst gjennom hans annen spillefilm, Bennys video fra 1992. Og i tilknytning til den norske lanseringen av denne filmen møtte jeg også Haneke selv til intervju. Den omtalte ambivalensen ble også min. Hanekes kritiske estetikk går ut på at konfrontasjon med ubehaget skal bidra til ettertanke. Ja, vi innser at han med ubehagelige bilder viser oss noe viktig, men vi har ikke alltid likt hvordan han viser oss det. Det er mange personlige rapporter om tilskuere som har ønsket å forlate salen, men som like fullt blir sittende grunnet dramaets alvor (3). Etter dette første møtet har jeg forsøkt å følge Hanekes filmvirke tett (ramme 1), og jeg har ved flere anledninger kommentert det $(4,5)$, senest med en tekst om fjorårets film Det hvite båndet (1).

Bennys video handler om omsorgssvikt i den øvre middelklasse. Her etablerer Haneke sine to mest sentrale temaer: familien og volden. Og de to kan ikke ses isolert fra hverandre. Filmen sjokkerte med sitt stive og beherskede portrett av en tenåringsgutt som dreper en jevnaldrende jente «for å se hvordan det var». Gutten forholder seg til det menneskelige, men lever på utsiden av det. Han erfarer sine medmennesker via video, fjernsyn og kameraer. Haneke grep slik direkte inn i en pågående diskusjon om medievold. Han ville avsløre den nonchalante omgangen med vold i mediene, især i Hollywood.

De egentlig hovedanklagede i filmen er foreldrene. Hanekes portrett er provoserende endimensjonalt. Foreldrene er mest opptatt av den ytre fasaden. Og når de innser at drapet har skjedd, forsøker de etter beste evne å dekke over misgjerningen. Haneke ser det slik at verden er i en kontinuerlig krigssituasjon, og at familiens misgjerninger er alle krigers opphav. Hans hat mot familien som institusjon er her så voldsomt at man tar seg i å undres over hvilken familie han tar det fra.

Jeg ble, som mange andre, dypt grepet av hvordan Haneke med nærmest kirurgisk radikalitet trenger inn under overflaten. Men jeg følte også behov for å ta avstand fra regissørens angrep på mine sanser og mitt sinn. Ambivalensen handlet om at vi ikke bare hadde behov for å ta avstand fra den ondskapen og destruktiviteten som Haneke har villet at vi skulle ta avstand fra, men også at vi fikk behov for å ta

\section{«Film er 24 løgner i sekundet i sann- hetens tjeneste, eller i tjenesten for å forsøke å finne sannheten.»}

Michael Haneke (2)

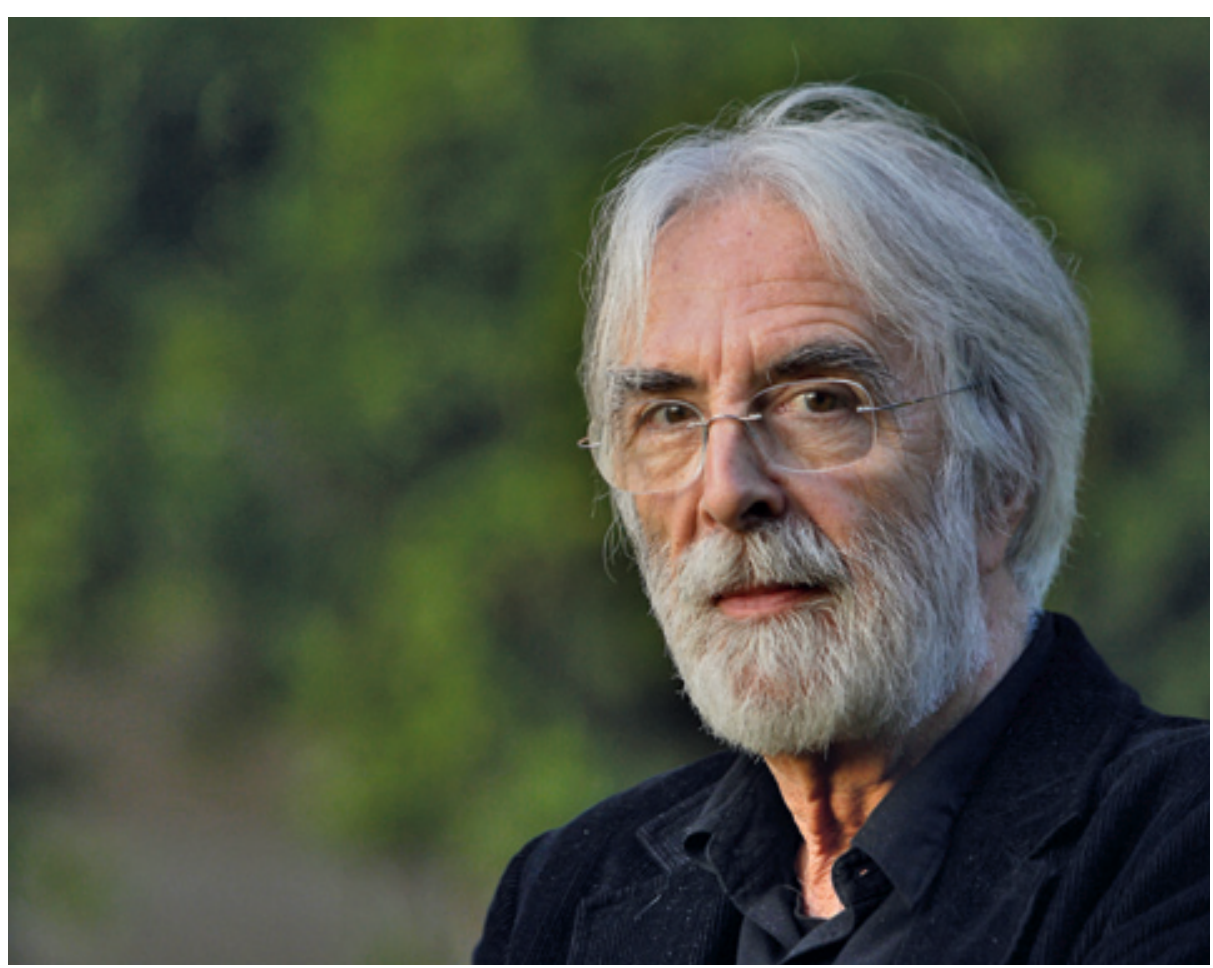

Michael Haneke. Foto ZUMA Press/SCANPIX 


\section{Ramme 1}

\author{
Filmografi spillefilmer \\ Der siebente Kontinent/Det syvende \\ kontinent (1989) \\ Benny's video (1992) \\ 71 Fragmente einer Chronologie des \\ Zufalls/71 fragmenter av tilfeldig- \\ hetens kronologi (1994) \\ Das Schloss (1997) \\ Funny games (1997) \\ Code inconnu/Ukjent kode (2000) \\ La pianiste/Pianolærerinnen (2001) \\ Le temps du loup/Ulvetimen (2003) \\ Caché/Skjult (2005) \\ Funny games U.S. (2007) \\ Das weisse Band/Det hvite båndet \\ (2009)
}

avstand fra Haneke. Hans tilnærming har vært eksplisitt aggressiv. Han har erklært at han «ville voldta tilskueren til selvstendighet» (2). Men slaget i øyet var også med hans første filmer et slag i tilliten til filmskaperen. Provokasjonen er et estetisk uttrykk med åpenbare begrensninger. Den kan stå i veien for kloke erkjennelser.

I denne teksten vil jeg kortfattet presentere Michael Hanekes filmvirke og, ikke minst, forsøke å beskrive hvordan han har modnet som kunstner. I sine to siste filmer, Skjult fra 2005 og Det hvite båndet fra 2009, er han langt nærmere ambisjonen om å få oss til å erkjenne via å kjenne (1). Disse to siste filmene viser en imponerende balanse mellom det problematiske - representasjonene av det onde - og det problematiserende - hvordan vi blir stimulert til selv å reflektere over det ondes problem. Filmviteren Catherine Wheatley har i sin bok Michael Haneke's cinema. The ethic of the image viet stor plass til det hun kaller «etisk refleksivitet» (3), altså en slik aktiv refleksjon om etiske spørsmål. Hanekes modning kommer til uttrykk som en dreining fra desperate dystopier til mer undrende melankoli. Hans aggressive modernisme er blitt noe mindre aggressiv.

\section{Hvem er Haneke?}

Michael Haneke ble født i München i 1942. Moren var skuespiller og faren både skuespiller og regissør. Haneke flyttet til Wien, og etter å ha mislyktes som skuespiller og musiker gikk han en lengre vei til filmregien via studier i filosofi, psykologi og drama. Han var en periode filmkritiker, senere ble han klipper og dramaturg i sørtysk TV. Filmdebuten fant sted i 1974 innefor TV-mediet. Som TV-regissør har han blant annet gitt bilder til Franz Kafkas roman Slottet. Etter at Haneke ble en internasjonal celebritet har også Das Schloss (1997) fått kinodistribusjon.

Det er hensiktsmessig å plassere Haneke i en nasjonal kulturell kontekst. I over hundre år har Østerrike produsert en betydningsfull rekke av kunstnere og kulturarbeidere som har spesialisert seg på avsløringen. Det kan se ut som om det finnes en nasjonal psykosomatikk som gir en særegen grobunn for en «mistankens hermeneutikk», der man søker å avsløre spillene i overflaten (6). Personligheter som Franz Grillparzer (1791-1872), Karl Kraus (1874-1936) og Hermann Broch (1886- 1951) har gått løs på dobbeltmonarki, dobbeltmoral og dobbeltspråk og dobbelte liv. Det var om sine landsmenn Sigmund Freud (1856-1939) skrev Ubehaget $i$ kulturen (7). Han skapte et nytt univers ut av spenningene mellom overflate og dybde. Utsiden kan både vise og skjule innsiden. Med utgangspunkt i de østerrikske borgernes liv lærte han oss om fortrengningens pris. Det som fortrenges og feies under teppet, risikerer å vende tilbake som nevrotisk sykelighet. Og den store freudianske følelsen er den samme som Haneke vil at vi skal utforske - skyldfølelsen.

Forfatterne Thomas Bernhard (1931-89) og Elfriede Jelinek (f. 1946) er nyere utgaver av kritiske, selvutmeldte og store kunstnere i dette landet. Og nå er de rasende. I den østerrikske filmen er Michael Haneke den fremste i en slik mistankens og provokasjonens tradisjon (8). I den franskproduserte Pianolcererinnen fra 2001 møttes Haneke og nobelprisvinner Jelinek. Haneke filmatiserte hennes roman med samme tittel (9). Boken er diskutert av undertegnede som en skjønnlitterær tematisering av selvskading i et tidligere nummer av Tidsskriftet (10). Isabelle Huppert spiller den kroppslig selvskadende og sadomasochistiske pianolærerinnen i Wien. Haneke sier selv om sin film at han bestrebet seg på «å lage en film som var obskøn, men ikke pornografisk» (8).

\section{Antipsykologisk film}

I sin egen tekst Film als Katharsis (2) gjør Haneke rede for sin filmpoetikk. Han beskriver sitt filmspråk som «antipsykologisk». Han er opptatt av den klargjørende avstanden, ofte med et distansert og kjølig kamera. Han viser til forbilder som franske Bresson og polske Kieslowski. Haneke er antipsykolog i den forstand at han lager rollefigurer som det ikke er meningen vi skal identifisere oss med. Vi får ikke vite nok om dem. Han vil at disse ikke-personene skal være som utydelige, blanke flater som vi projiserer vårt eget følelsesliv på. Tilskueren skal ikke åpne seg for skikkelsene som blir projisert på lerretet i form av identifikasjon, men bli åpen for seg selv.

Vi må selv lete oss frem gjennom råstoffet, få tid til å betrakte og tenke. Det er nærliggende med en Freud-referanse. Både Haneke og Freud arbeider med projeksjoner. Freud var tilsvarende opptatt av at han som terapeut skulle sitte bak divanen, slik at pasienten ikke kunne se hans ansikts- uttrykk. Ved å være nær, men samtidig fjern mente Freud at han gjorde seg til en projeksjonsfigur som stimulerte pasientens egne assosiasjoner. Den freudianske og den hanekeske metode kan begge oppleves som meget frustrerende for den som sitter/ligger der. Men rasjonalet for metoden er at den kan fremme innsikt og endring.

Og det er på slikt vis Haneke opponerer mot den amerikanske filmtradisjonen. Han forsøker å gi volden tilbake det den egentlig er: smerte og skade av den andre. Spørsmålet han stiller seg selv, er ikke «hvordan skal jeg vise vold?», heller «hvordan skal jeg vise tilskueren hans egen holdning til volden og dens uttrykk?». Hanekes kamera demper følelsene, da han mener at det emosjonelle kameraet leder til sentimentalitet og føleri, som igjen fører til konsensus og konsum $(3,8)$.

Stort sett skjuler han volden for oss. Vi forstår hva som skjer, men ser det ikke. Ifølge filmviteren og Haneke-kjenneren Mattias Frey (8) er han slik sett en antiTarantino (Pulp fiction og Kill Bill) og en anti-Stone (Natural born killers). Og han er en anti-Spielberg (Schindlers liste). Frey påpeker hvordan Hanekes filmiske metode har klare paralleller til diskusjonen om traumer, historie og hukommelse: Hvordan skal man fremstille holocaust? Haneke slutter seg her til Claude Lanzmann, dokumentaristen bak det store holocausteposet Shoah, ved at overgrepene tematiseres best ved at de ikke vises. Traumets smerte kan bli mest tydelig ved å vise hvor vondt det er å nærme seg det faktiske minnet.

\section{Utmattelsens estetikk}

Funny games fra 1997 er den av Hanekes filmer jeg finner mest problematisk. Men andre lot seg begeistre, faktisk slik at han ble invitert til å lage en amerikansk versjon, Funny Games U.S. i 2008. En familie med mor, far, sønn og hund drar til sitt sommerhus ved sjøen. Så kommer to overklassepsykopater i golfutstyr for å låne egg. På lydsiden, og i ansiktene til golfguttene, blir vi påtvunget en helaften sadistisk og umotivert slakt av en familie, inkludert hunden. Det er absolutt ikke funny. Den moralistiske Haneke tvinger oss til sterkt å ta avstand fra slik blind vold. Og det gjør vi. Men det er altså her jeg igjen får behov for å avstand fra Haneke. Med sin umenneskelige film tvinger han oss til å tenke rett - men det kjennes galt. Overdrivelsen vender seg mot filmen, som en stor mistillit til dens prosjekt. Vi er da ikke så ille. Vi stoler ikke på ham.

\section{Invitasjon til empati}

Så skjer det noe viktig. I Skjult fra 2005 innfrir Hanekes sitt eget program. Vi føler og tenker med (5). Filmen fikk stor internasjonal anerkjennelse og både kritikerprisen og regiprisen under Cannes-festivalen det året. Skjult tar utgangspunkt i en kultivert familie som blir overvåket. Bunnsolide 


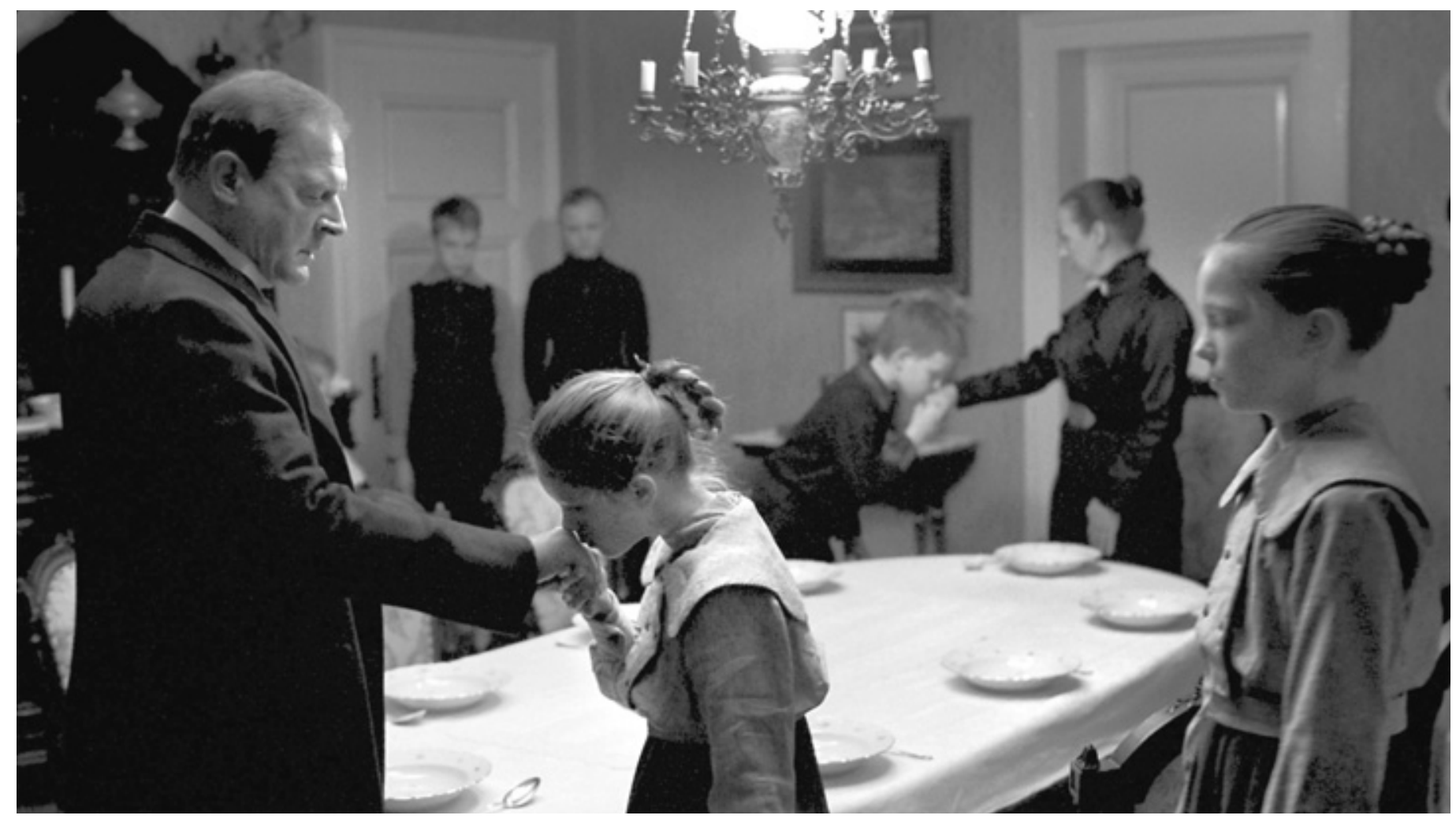

Scene fra Det hvite båndet. Foto Les Films du Losange/DPA/SCANPIX

skuespillerprestasjoner gjør dette til Hanekes inntil da mest tilgjengelige film. Daniel Auteuil gestalter en kultivert programleder for et bokmagasin på fransk fjernsyn. Hans kone, spilt av Juliette Binoche, er forlagsredaktør. En dag får de en videokassett i posten. Noen filmer dem i det skjulte utenfor den smakfulle boligen i Paris. Videoene blir flere og mer makabre og personlige. Det kommer også underlige barnetegninger. Familien forsøker å holde fasaden, men den ukjente avsenderen går dem på nervene og får frem skjulte sider ved familieidyllen. Langsomt kveles tilliten, og uro og paranoia sprer seg. Aftenpostens filmkritiker Per Haddal skrev at Haneke «har full kontroll over spenninger, stemninger og tempo, det vil si at han taler thrillerspråket flytende. Og det er som om Kafka og Hitchcock slår seg sammen» (11).

Og han er dyktigere enn noen gang, en freudiansk agent med temaene fortrengning og skyld. Med slike følelsesmessige reaksjoner som nøkler blir vi introdusert for en rekke konflikter og temaer. Filmen kan leses på uendelig mange forskjellige måter: politisk, etisk, etnisk, psykologisk osv. Den kan ses som en film om barnet og skylden, foreldrenes svik av barnet, overklasse versus underklasse, de dannede innvandrere mot de udannede hvite, bevissthet versus underbevissthet, Frankrike versus Algerie, mann versus kvinne osv.

Haneke har sluttet å stenge oss ute med ubehaget. Nå viser han til et ubehag, men han lar det være opp til oss hvordan vi skal forstå det. Og han gir oss skikkelser som vi alle kan føle med, også de rollefigurene som ikke lærer av sine feil. Vi føler oss invitert inn i den etiske og mentaliserende undringen. $\mathrm{Og}$ noen av portrettene er de varmeste Haneke noen gang har produsert.

Kameraet er fortsatt distansert, ingen musikk driver opp stemningen, og noen scener er frekt langsomme. Haneke registrerer stille og nøkternt, og vi rives med i ettertanke om hva det er vi ikke orker å ta innover oss. Og hvilken pris vi må betale for det? I dette verket demonstrerer Haneke selv hvor stor forskjell det er på kunstverk som er henholdsvis lukkende og åpnende. Skjult er åpen i flere ender, som et godt dikt.

\section{Det hvite båndet}

\section{og den svarte pedagogikken}

Med Det hvite båndet bekrefter Haneke sin modning som filmpoet og etiker (1). Filmen er gjentatte ganger blitt erklært som mesterverk, og den har vunnet og er blitt nominert til en rekke priser. Den vant den prestisjetunge Gulløven i Cannes. Det er en storslagen film, ja nesten for perfekt, i betydningen klinisk renset, utstudert, gjennomtenkt og teknisk briljant. Og Haneke er kanskje noe mer belærende enn i Skjult. Han vet best og har noe han vil fortelle oss om hvorfor det går galt her i verden.

Og igjen er det foreldrene og deres misgjerninger. Det hvite båndet kalles en barnefortelling. Det er fortelling om barn, men den er mest for voksne. Den viser hvordan voksne kan gjøre barn onde. Det berettes en historie fra fortiden, om livet i en nordtysk landsby i årene 1913 og 1914. Forteller- stemmen mener de mystiske ulykkene og overgrepene her kan kaste lys over noe av det som senere skjedde i dette landet. Det som blant annet skjedde, var altså utbruddet av den første verdenskrig, fascismens fremvekst, den annen verdenskrig og holocaust. Med en slik tematikk demonstrerer filmskaperen en tydelig konsekvens - oppvekst, familieliv, vold og krenkelser.

De voksne i landsbyen oppdrar neste generasjon med tukt, frykt, slag og krenkelser. Det etterlater en stemning så kuende at man kan føle at voldsorgiene under den første verdenskrig var som en uunngåelig utagering av denne. Tematisk kan det være som Bergmans Fanny og Alexander møter William Goldings Lord of the flies. Den første handler om barn som blir krenket, den siste om barn som krenkere. Den tyske landsbyen er kuet av den menneske- og lystfiendtlige lutheranismen, og det hvite båndet er symbolet presten tvinger sine barn til å bære som synlig tegn på at mennesket er syndig og urent. Båndet representerer aktiv påføring av skam på barna. Presten og de andre foreldrene i landsbyen står med sin kustus for det som den nylig avdøde sveitsiske psykoanalytikeren Alice Miller har kalt «den svarte pedagogikken» (12). Tillat meg å sitere fra min egen alvorlige språklek om farger i min omtale av filmen i forbindelse med lanseringen i Norge: «Det hvite båndet og den svarte pedagogikken utløser et krenkelsens raseri, som senere munner ut i røde blodstenkte bandasjer, gule stjerner, brune skjorter og Europas grønne sletter med millioner av lik» (1). Fargesymbo- 
likken blir forsterket av at det hele blir berettet i poetiske svart-hvitt-bilder.

Og igjen henter Haneke filmspråklige grep fra thrilleren. Det hvite båndet er som en detektivfortelling med ukjent gjerningsperson hvor vi må løse mye av gåten selv. Filmspråket er stramt - med kontrollfrikens sans for presisjon, timing og minimal bruk av lyd til å drive opp stemningen. Det er rent og vakkert vondt. Haneke har selv sagt at han ikke ønsker at denne filmen skal bli redusert til en film kun om tysk fascisme. Ethvert ideal kan bli pervertert når det blir et absolutt. Dette er ikke bare en film om det tyske problemet, det er en film om oppdragelsens problem og alles problem.

\section{Bildenes etikk}

Etiske konflikter er gjenstand for vedvarende bearbeiding gjennom filosofi, skjønnlitteratur, poesi, drama og film. Ideer og handlinger blir gjort synlig og problematisert. Etikk er simpelthen en av kunstens største anliggender. Når den etiske diskursen omkring skyld og ansvar former temaene hos Haneke, kan han således ikke skryte på seg noen form for originalitet. Hans originalitet ligger $i$ at han ikke bare behandler temaer som selvmord, mord, vold og voldtekt på et narrativt plan, men at han med filmenes estetiske løsninger forsøker å aktivere tilskuerens forhold til seg selv og sin egen etikk $(2,3,8)$. Det viktigste skjer ikke på lerretet, påstår Haneke, det viktigste er relasjonen mellom det som vises og den som det blir vist til. Han er opptatt av det etiske tilskuerskapet, hvor et sentralt element både er tilskuerens refleksjon over sin egen moral, men også over selve erfaringen som tilskuer. Å være en etisk tilskuer handler for Haneke om å bli mer kritisk til hva man opplever i filmteateret.

Haneke har ifølge Wheatley (3) $i$ arbeidet med enhver ny film vært meget systematisk i det å ta på alvor tilskuernes respons på de tidligere filmene. Den nye filmen er således hans respons på tilskuernes problematiserende responser. Slik forsøker han å konkretisere den aktive relasjonen mellom regissør og tilskuer til å bli en del av hans egen kreative prosess.
Ett av Hanekes skjellsord når det gjelder filmmediet er «konsum» $(2,8)$. Film skal ikke være forbruksvare, noe han mener den amerikanske filmen i hovedsak er blitt. Den skal i stedet bidra til å forstyrre, det vil si å føre til nye etiske og psykologiske erfaringer. $\mathrm{Og}$ han anvender da meget bevisst det som kan kalles refleksive teknikker. Deri ligger hans originalitet. Dette er, som allerede beskrevet, estetiske grep som spørsmål uten svar, manglende informasjon og kjølig kameraføring samt distanse til rollefigurene for å unngå sentimental identifisering med dem. De voksne aktørene i Det hvite båndet har ikke navn, de kalles Presten, Læreren, Doktoren og Baronen.

Som filmskaper er Michael Haneke en stor og meget bevisst manipulator. Han vil noe med oss. Om vi trer vekk fra filmens og tilskuerens egen retorikk og i stedet tyr til psykologiske og medisinske begreper, kan man beskrive ham som en filmskaper med store ambisjoner om å stimulere til mentalisering - det vil si fremelske undring og nysgjerrighet omkring ens egne og andres følelser, tanker, hensikter, lyster og motiver, simpelthen vårt indre liv (13). Og mentalisering som mental og sosiale kompetanse har etiske sider. Om man anstrenger seg for «å se andre fra innsiden», er det vanskeligere å se mennesker som ting. Menneskene blir mer menneskelige og slik sett vanskeligere å skade. Og dersom man forsøker «å se seg selv fra innsiden», kan man forstå bedre hvordan man påvirker andre.

I et slikt psykologisk-etisk perspektiv er det høyst interessant hvordan Haneke arbeider estetisk i filmmediet for å søke balansen mellom kontrastene nærhet avstand, varme - kulde og identifikasjon ikke-identifikasjon. Jeg velger å fortolke ham som en filmskaper som har innsett ett av filmmediets største svakheter. Mediets åpenbare styrke, men også dets store svakhet, er den sterke opplevelsen av noe konkret. Med stimulering av mange av våre sanser risikerer dette mediet å bli overtydelig og slik tappet for symbolsk og metaforisk rom. Filmmediets konkrethet kan skape en identifikasjon som emosjonelt er sterk og overbevisende, men som hemmer refleksjonen. Michael Haneke bruker bevisst avstand i et så emosjonelt sterkt engasjerende medium som filmen til å fremme nærhet til reflekterende nysgjerrighet, han bruker ikke-involvering til å stimulere til involvering $i$ ens eget og andres sinn, og han bruker kulde til å lage refleksiv varme. Og han forsøker altså å anvende det han selv kaller ikkepsykologi til å fremme psykologisk ettertanke.

Oppgitte interessekonflikter: Finn Skårderud har mottatt engangshonorar fra filmdistributøren Arthaus i forbindelse med en bestilt tekst og foredrag om en av Hanekes filmer.

\section{Litteratur}

1. Skårderud F. Svart og hvitt. Om filmskaperen Michael Haneke og «Det hvite båndet». www filmweb.no/arthaus/kommer/ article216978.ece (7.6.2010)

2 Haneke M. Film als Katharsis. I: Bono F, red. Austria (in)felix: Zum österreichischen Film der 80er Jahre. Graz: Edition Blimp, 1992: 89.

3. Wheatley C. Michael Haneke's cinema. The ethic of the image. New York: Berghahn Books, 2009.

4. Skårderud F. Utmattelsens estetikk. 71 fragmenter av tilfeldighetens kronologi. Michael Haneke. Film \& Kino 1995: nr. 4: 4-7.

5. Skårderud F. Ubehag og ettertanke. Tekst til DVDutgave av Michael Hanekes film «Skjult». Oslo: Arthaus, 2006.

6. Skårderud F. Uro. En reise i det moderne selvet. Oslo: Aschehoug, 1998

7. Freud S. Ubehaget i kulturen. Oslo: Cappelen, 1992

8. Frey M. A cinema of disturbance: the films of Michael Haneke in context. Senses of Cinema. http://archive.sensesofcinema.com/contents/ directors/03/haneke.html (13.2.2010).

9. Jelinek E. Pianolærerinnen. Oslo: Gyldendal, 2005.

10. Skårderud F. Kroppens tekster. Selvskading skjønnlitteratur. Tidsskr Nor Legeforen 2009. 129: 773-5

11. Haddal P. Nådeløs thriller. Anmeldelse av Michael Hanekes «Skjult». Aftenposten 9.2.2006.

12. Miller A. I begynnelsen var oppdragelsen. Oslo: Gyldendal, 1986.

13. Skårderud F, Sommerfeldt B. Mentalisering et nytt teoretisk og terapeutisk begrep. Tidsskr Nor Legeforen 2008; 128: 1066-9.

Manuskriptet ble mottatt 14.2. 2010 og godkjent 1.7. 2010. Medisinsk redaktør Anne Gitte Hertzberg. 